\title{
スリット付き海水交換型防波堤および 鉛直混合型護岸の開発 DEVELOPMENT OF WATER-EXCHANGING BREAKWATER AND VERTICALLY WATER-MIXING WHARF WITH SLITS
}

\author{
島田潔 1 吉村正 2 ・杉本達彦 3 ・丸山文生 4 ・五十嵐和之 5 \\ Kiyoshi SHIMADA, Tadashi YOSHIMURA, Tatsuhiko SUGIMOTO, \\ Fumio MARUYAMA and Kazuyuki IGARASHI

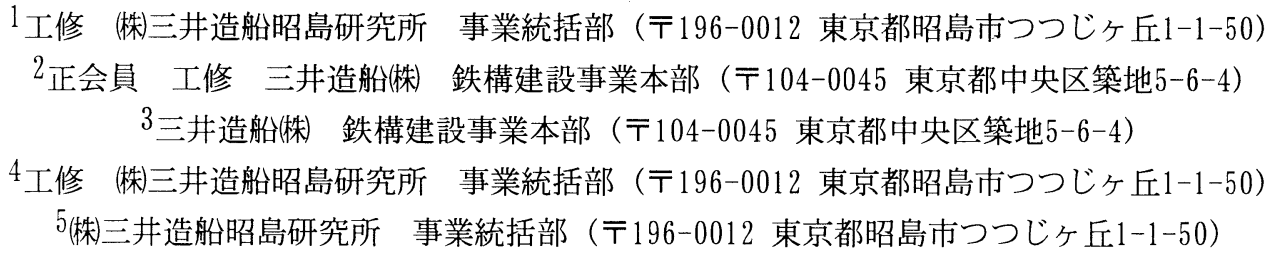

A model experiment is conducted to investigate water-exchange performance of newly-developed breakwater with vertical slits. It is confirmed that a large amount of water can be introduced to the backside area of the breakwater. Variation of submergence area of the slits due to tide change has no significant effect on the waterexchange performance of the breakwater, which is advantageous for the breakwater to be used in the large-tidechanging inland sea.

Also conducted is a model experiment for a vertically water-mixing wharf, which shows more than the amount of surface water obtained in the breakwater experiment is introduced to the bottom layer in front of the wharf.

Key Words : Water exchange, vertical water mixture, slit, breakwater, wharf

\section{1.はじめに}

防波堤は港外からの波浪の進入を防ぐと同時に港 外の海水の流入も抑えるため, 港内の海水が滞留し, 水質の悪化が生じることが多い。また，底層に滞留 した海水は密度の関係から上昇することがなく, 水 面からの酸素供給が期待できないため, 水質が悪化

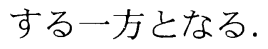

本論では, 簡易な構造を有するスリット付き防波 堤ケーソンに対して水理実験を行い, 導水能力を調 査するとともに, 導水能力に対するスリット長さの 影響についても調査した。

また，導水口をケーソン前面の下部に設けた護岸 タイプに対しても水理実験を行い, 海水の鉛直混合 を可能とする底層部への導水能力について調查した.

\section{2. 供試模型}

海水交換型防波堤の供試模型の概略図を，図 1 お よび図 2 に示す. 図 2 に示すように, 供試模型は 5 室に区切られており，1室当たり 3 本の縦スリット が切られている。水面を切るスリットの割合は $40 \%$ である。

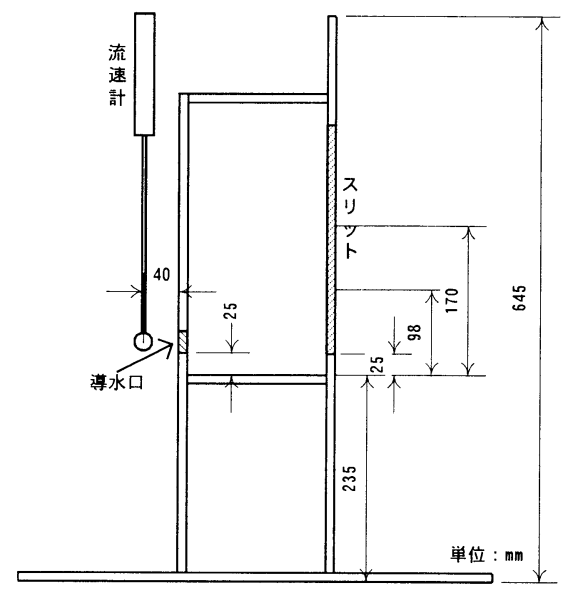

図-1 海水交換型防波堤模型（断面図） 


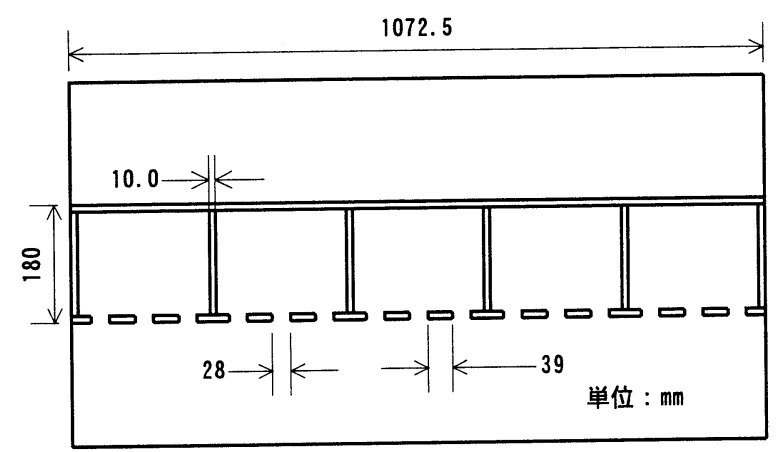

図-2 海水交換型防波堤模型（平面図）

図 3 は, 海水交換型防波堤模型のスリットおよび 背面開口部の大きさを示したものである. 背面開口 部は各室に 1 個設け, スリット長さは 3 種類変化さ せて実験を実施した。

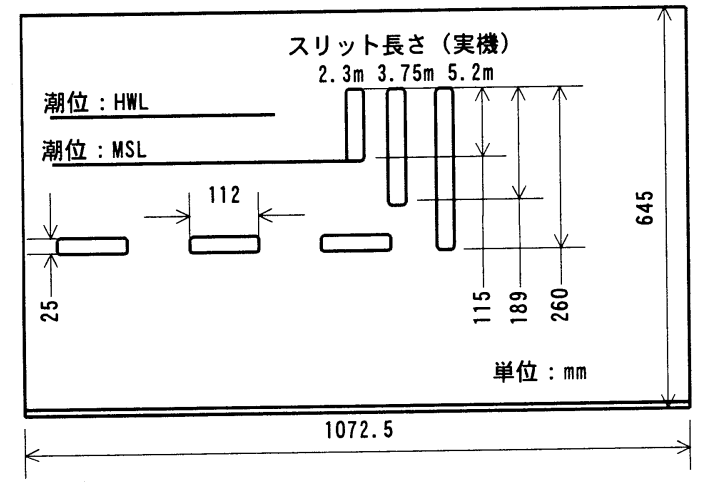

図-3 海水交換型防波堤のスリット および導水口の形状

鉛直混合型護岸模型は海水交換型防波堤模型の背 面開口部を塞ぎ，各室の床面および前面下部に開口 部を設けたものである．海水交換型防波堤および鉛 直混合型護岸の導水の流れを図 4 に模式的に示す.

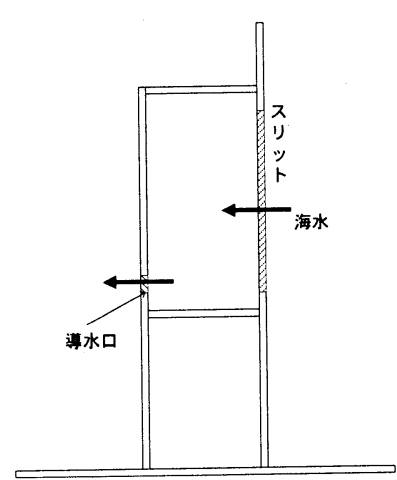

（海水交換型防波堤）

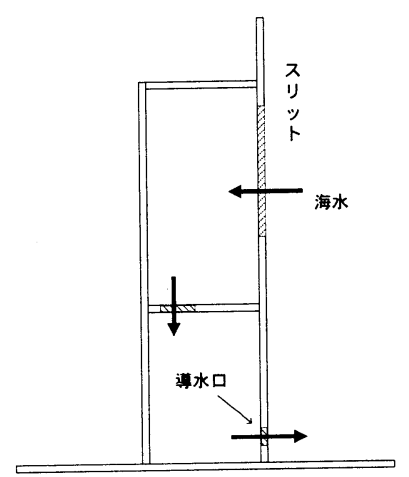

（鉛直混合型護岸）
図-4 導水の流れ

\section{3. 実験パラメータ}

実験パラメータを，実機ベースで表-1にまとめる.

\begin{tabular}{|c|c|c|}
\hline & 海水交換型防波堤 & 鉛直混合型護岸 \\
\hline 则ッ長さ & $2.3,3.75,5.2 \mathrm{~m}$ & $3.75 \mathrm{~m}$ \\
\hline 波周期 & \multicolumn{2}{|c|}{$2.9 \sim 8.0 \mathrm{~s}$} \\
\hline 波高 & \multicolumn{2}{|c|}{$0.8 \mathrm{~m}$} \\
\hline 水深 & $18.7,20.2 \mathrm{~m}$ & $18.7 \mathrm{~m}$ \\
\hline 潮位 & MSL, HWL & MSL \\
\hline
\end{tabular}

\section{4. 実験方法}

図 5 に海水交換型防波堤実験のセットアップを示 す。規則波を数波発生させ，1 本のサーボ式波高計 によって入射波と反射波を完全分離状態で計測した. 防波堤背面の透過波もサーボ式波高計によって計測 した. また，防波堤背面の開口部における流速を電 磁流速計で計測した.

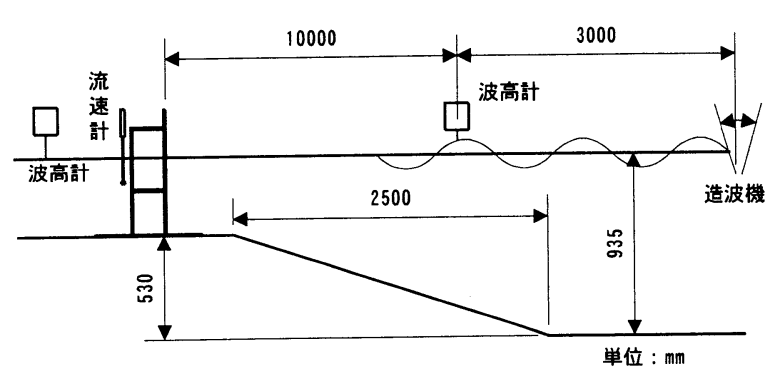

図-5 海水交換型防波堤実験のセットアップ

鉛直混合型護岸実験の場合には，模型の前面下部 に設けた導水口の中央に流速計をセットし, 導水流 速を計測した。

入射波, 反射波, 透過波についてはフーリエ解析 を行い， 1 次振幅についてまとめた. 導水量につい ては, 流速の定常成分に開口部面積を乗じて求めた.

\section{5. 実験結果}

\section{（1）反射率}

海水交換型防波堤の反射率の実験結果を図 6 に示 す。スリット長さが $3.75 \mathrm{~m}$ と $5.2 \mathrm{~m}$ の場合には，0.5以 下の良好な反射特性を示している. 特に設計周期で ある 4 秒付近の入射波に対しては，0.4を切る反射 率となっている.

スリット長さが 2.3 の場合には, 反射率は他のス 
リット長さに対する結果の 2 倍程度にもなっている. これは, スリット長さが $2.3 \mathrm{~m}$ の場合には, 静止水面 下にスリットがない状態であり, スリットによる波 エネルギーの散逸効果がほとんど発揮できないため と考えられる.

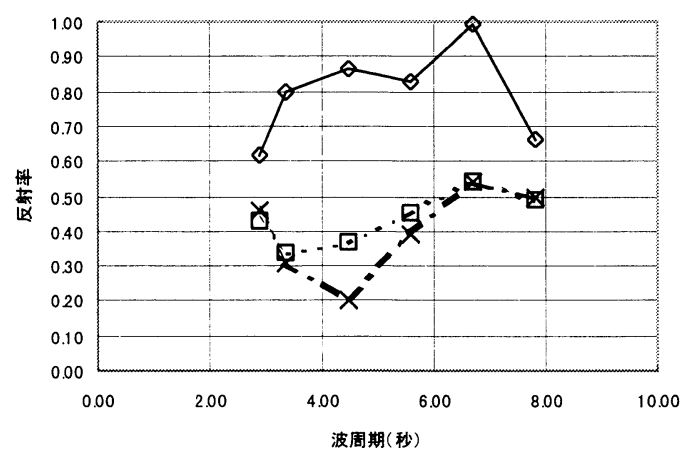

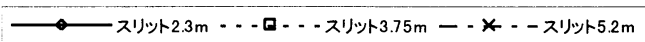

図-6 反射率（水位：MSL，波高：0.8m）

\section{（2）透過率}

海水交換型防波堤の透過率の実験結果を図 7 に示 す. スリットが長い程, 透過率が大きくなる傾向が 見られている.これは, 背面導水口の位置が高いた め, スリットが長い場合にはスリットの下部を通り 抜けた水がそのまま導水口を通り抜けるためと考え られる。
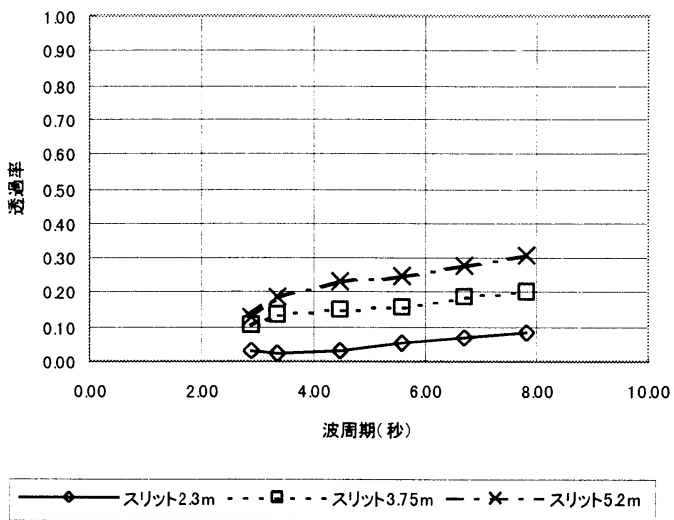

図-7 透過率（水位：MSL，波高：0.8m）

\section{（3）導水量}

海水交換型防波堤の導水量の実験結果を図 8 に示 す. 図 8 に示す導水量は, 長さ $1 \mathrm{~m}$ の防波堤で 1 時 間当たりに得られるものである. スリット長さが $2.3 \mathrm{~m}$ 場合に, 他の場合に比べて若干導水量が少な くなっているが， $400 \mathrm{~m}^{3}$ を越える導水量が得られて いることがわかる. また, 導水量に及ぼすスリット 長さの影響は，あまり顕著ではないと言える.

スリット有効深さと入射波高の比 (d/H) を横軸に とり, 無次元導水量として表したものを図 9 に示す.
無次元導水量は, 静止水面を越える入射波の水量 （HL $/ 2 \pi ）$ に対する割合として表したものである. スリット有効深さとは, スリットの没水部開口面積 を防波堤の長さで除したものである. 図中には衝立 パネル方式の場合の結果 ${ }^{1)}$ を比較のために示してあ る．衝立パネル方式の場合には，dは衝立パネルの 没水深さに対応する.
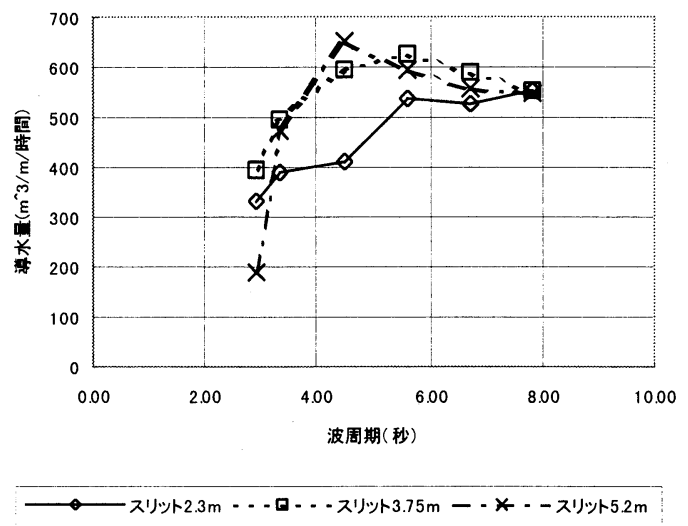

図-8 導水量（水位：MSL, 波高 : $0.8 \mathrm{~m}$ ）

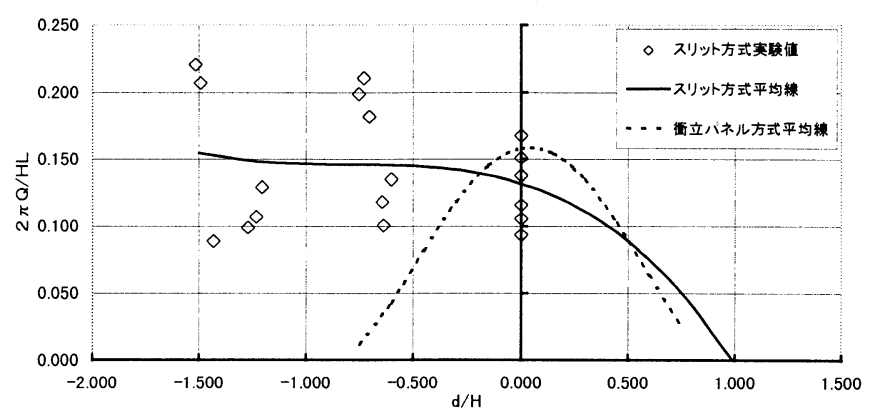

図-9 無次元導水量

衝立パネル方式の場合には，潮位変化による衝立 パネルの没水深さが導水量に大きく影響する結果と なっている. 衝立パネル上端が水面付近 $(\mathrm{d} / \mathrm{H}=$ 0.0）にあるときに最も導水量が多くなり, 衝立パ ネルが高くなっても低くなっても導水量は減少する. 一方, スリット方式の場合には, 潮位変化によるス リットの没水度が導水量に及ぼす影響はあまり顕著 ではなく, d/Hが負の場青でも安定した導水量が確 保できるという結果が得られている.

図10は，海水交換型防波堤と鉛直混合型護岸で得 られた導水量を比較して示したものである. 図中に 示す導水量は, $1 \mathrm{~m}$ の防波堤あるいは護岸が, 波高 $1 \mathrm{~m}$ の海象条件下で 1 時間当たりに得る導水量であ る. 3 秒付近の短周期の入射波に対しては, 両者の 導水量にはほとんど差がないが，入射波周期が長く なるにつれて防波堤の場合には導水量が減少し, 護 岸の場合は増加する傾向が見られている.

防波堤の場合には背面の水位変化がないため, 導 
水量は防波堤ケーソン内部の水位のみに依存すると 考えられる. 一方, 護岸の場合には, 導水量は前面 の水位変化にも依存すると考えられる. 短周期の波 の場合には, 前面の水位変動の影響が護岸ケーソン 下部の導水口まで伝わらないが，入射波周期が長く なるにつれて前面の水位変動の影響が導水口まで伝 わることになる. 引き波状態で前面水位が静止水面 よりも下がった場合にも, 護岸ケーソン内部の水位 との差により前面への導水量が得られるため, 防波 堤の場合の背面への導水量よりも増加したものと考 えられる。

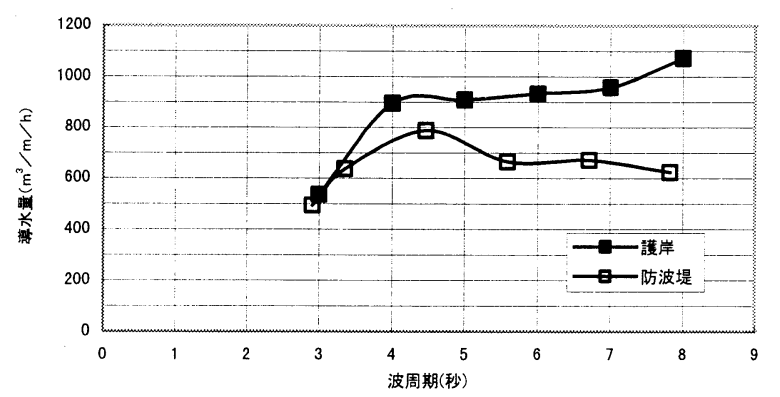

図-10 海水交換型防波堤と鉛直混合型護岸の導水 量（長さ $1 \mathrm{~m} ，$ 波高 $1 \mathrm{~m} ， 1$ 時間当たり）

\section{6. 終わりに}

構造が非常に簡単なスリット付きの海水交換型防 波堤および鉛直混合型護岸に対して規則波中実験を 実施し，海水交換能力あるいは海水の鉛直混合能力 が十分あることを確認した．本形式の防波堤を用い ることで，内部水域の海水交換が十分行われ，水質 悪化を防ぐことが可能と考えられる.

また，本形式のケーソンを護岸として用いた場合 には，水面付近の溶存酸素の豊富な海水を貧酸素の 底層に供給することができ，底層水の水質改善に効 果を発揮するものと期待できる.

\section{参考文献}

1）島田潔，ほか：衝立パネル式ケーソンの海水交換特性 に関する実験的研究, 海洋開発論文集, 第 15 巻, pp. 433-437, 1999. 